Cornell University Law School Scholarship@Cornell Law: A Digital Repository

Cornell Law Faculty Publications

4-29-2008

\title{
Finding and Citing the "Unimportant" Decisions of the U.S. Courts of Appeals
}

Peter W.Martin

Cornell Law School, peter.martin@cornell.edu

Follow this and additional works at: http://scholarship.law.cornell.edu/lsrp_papers

Part of the Courts Commons

\section{Recommended Citation}

Martin, Peter W., "Finding and Citing the "Unimportant" Decisions of the U.S. Courts of Appeals" (2008). Cornell Law Faculty Publications. Paper 102.

http://scholarship.law.cornell.edu/lsrp_papers/102

This Article is brought to you for free and open access by Scholarship@Cornell Law: A Digital Repository. It has been accepted for inclusion in Cornell Law Faculty Publications by an authorized administrator of Scholarship@Cornell Law: A Digital Repository. For more information, please contact jmp8@cornell.edu. 


\title{
CORNELL LAW SCHOOL
}

\section{LeGal Studies ReseArCh PAPER Series}

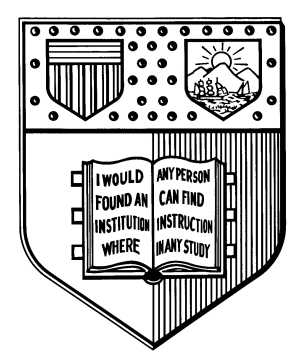

\section{Finding and Citing the "Unimportant" Decisions of the U.S. Courts of Appeals}

\author{
Peter W. Martin
}

\author{
Cornell Law School \\ Myron Taylor Hall \\ Ithaca, NY 14853-4901
}

Cornell Law School research paper No. 08-015

This paper can be downloaded without charge from:

The Social Science Research Network Electronic Paper Collection:

http://ssrn.com/abstract $=1125484$ 


\title{
Finding and Citing the "Unimportant" Decisions of the U.S. Courts of Appeals*
}

\author{
Peter W. Martin**

\section{Introduction}

『1 While a judge on the U.S. Court of Appeals for the Third Circuit, Supreme Court Justice Samuel A. Alito chaired the Advisory Committee on the Federal Rules of Appellate Procedure. In that capacity he led a lengthy study of the diverse circuit court rules governing the withholding of vast numbers of "unimportant" or "routine" opinions from publication and limiting citation of such "unpublished" opinions. (Also sitting as a member of the same committee was a judge of the D.C. Circuit, now Chief Justice of the Supreme Court, John G. Roberts, Jr.) In the face of judicial resistance that ranged from mild to fierce, the committee recommended a new rule overturning all past circuit policies forbidding the citation of unpublished opinions. With some revision by the Judicial Conference of the United States and after a year's delay, that recommended rule was adopted. Issued by the Supreme Court as Rule 32.1 of the Federal Rules of Appellate Procedure (FRAP), it took effect on December 1, 2006.[1] The new rule assures that all federal court decisions issued after January 1, 2007 may be cited, notwithstanding their being designated "unpublished," "not for publication," "nonprecedential,” or "not precedent” by the deciding court. This altered the situation in at least four circuits of the U.S. Courts of Appeals where citation of unpublished or nonprecedential decisions had previously been severely restricted or discouraged (namely, the Second, Seventh, Ninth, and Federal Circuits).[2]

T2 Responding to concerns about access to unpublished opinions, especially on the part of those unable or unwilling to pay the high prices of Lexis or Westlaw (both of which have for years loaded all the unpublished Court of Appeals decisions they could obtain), Justice Alito's committee pointed out that the EGovernment Act of 2002[3] mandated the federal courts (trial courts as well as appellate) to place all their opinions on public Web sites in a text-searchable format - "regardless of whether such opinions are to be published in the official court reporter." [4] Wrote the committee: "The disparity between litigants who are wealthy and those who are not is an unfortunate reality. Undoubtedly, some litigants have better access to unpublished opinions, just as some litigants have better access to published opinions, statutes, law review articles - or, for that matter, lawyers.”[5] But the report continued: “[T]he solution is found in 
measures such as the E-Government Act, which makes unpublished opinions widely available at little or no cost.”[6]

93 Sadly, the federal courts' implementation of the E-Government Act's opinion dissemination provisions falls far short of assuring effective access "at little or no cost." Since federal judges and those who serve them have unlimited use of Westlaw and Lexis,[7] the failure has been largely invisible to those in a position to bring about a different result. For much the same reason, the problem seems to have escaped attention from the many legal academics who have weighed in on the issues surrounding treatment of unpublished or nonprecedential decisions.[8] This report surveys the difficulties that currently confront non-subscribers to Westlaw or Lexis who would seek to take advantage of the new rule, difficulties in searching for, retrieving, and citing "unpublished" or "nonprecedential” decisions of the U.S. Circuit Courts of Appeals. It also notes straightforward steps the federal judiciary might take that would fulfill the promise of the E-Government Act's provisions.

\section{Some Metrics}

T4 During fiscal year 2007, the U.S. Circuit Courts of Appeals issued over 26,000 unpublished or nonprecedential decisions. Taken together they constituted $83.5 \%$ of all dispositions on the merits.[9] In numbers and percentage this category has grown enormously since the practice of issuing unpublished decisions began. In 1981, only 1,303 out of 12,070 circuit court opinions (11.2\%) were unpublished.[10]

\section{Finding Relevant Nonprecedential Decisions in Print and Online}

\section{Lexis, Westlaw, and Thomson's Federal Appendix}

I5 Strangely, publication of decisions of the lower federal courts, including the Circuit Courts of Appeals, has never been a governmental function.[11] While decisions of the U.S. Supreme Court are compiled and printed in an official edition, the United States Reports, published by the Government Printing Office, there is no comparable public or official set of law reports into which Court of Appeals decisions are compiled. Putting aside reports or services limited to particular legal topics (patent, tax, or securities law, for example), the only print publication through which they have been regularly and systematically disseminated is the Federal Reporter of Thomson / West (formerly the West Publishing Company). In pre-digital days, a federal appeals court acted on its conclusion that a particular opinion was insufficiently important to warrant publication simply by withholding the document from this one commercial publisher. During the 1980s, Lexis began to load all decisions of the Courts of 
Appeals that it could gather, whether or not published in the Federal Reporter, into its online service. In short order West followed suit with its Westlaw service. By the mid 1990s both Westlaw and Lexis offered extensive collections of "unpublished" decisions from nearly all the circuits. By 2005, they had achieved coverage of all thirteen.

96 Four years earlier, in late 2001, Thomson / West introduced a new set of law reports alongside the Federal Reporter, which it denominated the Federal Appendix. The avowed aim of this new series was to bring to print all those Court of Appeals decisions the judges had not selected for publication in the Federal Reporter, but which Lexis and Westlaw were, nonetheless, distributing. Taking this anachronistic venture at face value, one commentator observed:

Unpublished opinions are now published in every relevant sense. They are printed in bound volumes, are available on law library shelves, come complete with West Key Numbers, and even have their own citation format....[12]

But try to find these volumes on a library shelf. Confronted with a new reporter that threatened already strained budgets and limited shelf space and that duplicated material available on Lexis and Westlaw, librarians declined the offer.[13] So did most federal judges despite the publisher's offer of complimentary subscriptions.[14] Even free the books demand space, lots of it. Launched in September 2001, the Federal Appendix climbed past volume 200, in less than six years, devouring shelf space at an average annual rate of 6.2 feet.[15]

I7 The unenthusiastic market response to this new set of books cannot have surprised the publisher. It seems clear now and should have been clear at the time that Thomson / West did not produce these volumes of nonprecedential opinions in order to sell them, but instead to block or at least slow any move on the part of the federal judiciary to a system of non-proprietary, medium neutral citation like those adopted in over a dozen states. A related aim appears to have been to increase the competitive advantage of Westlaw over Lexis, particularly among federal judges and lawyers engaged in federal practice. Drawing upon the Federal Reporter brand together with its standard editorial components (synopsis, headnotes, key numbers) and conforming to citation norms still tied to volume and page numbers, the Federal Appendix has, in effect, amounted to the addition of a set of familiar features to Westlaw's online collection of nonprecedential Court of Appeals decisions, with the results archived to a small number of print sets. Viewed as a print publication, it has not significantly expanded access to this category of decisions. For that matter, it has not even achieved the publisher's aim of capturing all of them.[16] 


\section{The Courts' Own Sites}

98 Had all thirteen circuit courts complied with the injunction of the EGovernment Act, court Web sites would by be, as Justice Alito's report imagined, a significant point of access. By the act's terms there should now be for each circuit a Web site holding all opinions, whether or not designated by the court for publication, "in text searchable form." (The effective date for this provision was April 16, 2005.) Reasonably construed, the phrase "text searchable" implies that those sites should do more than store decisions behind an interface requiring users to know the docket number, date of decision, or the name of one of the parties in order to retrieve a case.[17] Yet to date only eight out of thirteen circuit sites have search engines that allow retrieval of decisions by means of key words or phrases.[18] One of that group, the First Circuit's site, has such a search feature, but had, as of the date of this paper, failed to index the last six years of the court's decisions.[19] Another, the site of the Ninth Circuit, exhibits similar inattention to currency and also limits full text search to precedential decisions.[20]

\section{Google}

T9 Even the best circuit court search engines (such as those of the Third, Fourth, and Fifth Circuits) do not match the power or sophistication of today's general purpose Internet search services. There is no reason they need do so. So long as the federal court sites are open to indexing by Google and its competitors, public access to their decisions via word search need not depend on the capability of their own search engines. While none of the federal circuit court sites go so far as to incorporate Google as their vehicle for searching opinions (as does the site of the Supreme Judicial Court of Maine[21]), all but those of the Fourth, Seventh, Tenth, and D.C. Circuits are open to external indexing and search.[22] As a consequence, one can search all the opinions (precedential and nonprecedential) at the site of the Federal Circuit Court of Appeals, one of the circuits with no internal search engine, by means of a Google search limited through inclusion of the term site:www.cafc.uscourts.gov. Moreover, since the Federal Circuit, unlike some of the others, tags its nonprecedential decisions with a distinctive phrase, indeed, one that changed slightly upon the effective date of FRAP 32.1, it is possible to conduct a Google search that either excludes nonprecedential decisions or is limited to them. The following illustrative search is designed to retrieve nonprecedential but citable Federal Circuit patent decisions that discuss the "obviousness" standard:

site:www.cafc.uscourts.gov patent obviousness "is nonprecedential". 


\section{The LII}

\10 On issues of patent law and other fields within the specialized jurisdiction of the Federal Circuit, the ability to conduct a Google search of all the decisions at this one site holds significant value. On most federal law questions, however, the twelve regional circuits possess parallel jurisdiction. Those researching a question of copyright or ERISA or federal criminal law may want to begin with a single circuit's jurisprudence, but depending on what that initial investigation yields will often want to follow with a search of decisions from the other circuits. Unfortunately, the E-Government Act speaks to each federal court individually. Consequently, even if every circuit court were in full compliance, anyone researching such an issue would have to contend with thirteen separately searchable sites, each employing a distinct format, mode of designating precedential and nonprecedential opinions, and interface.

ף11 Westlaw and Lexis solve this problem by gathering all Court of Appeals decisions into their respective database structures and reworking them into a consistent format. For over eight years, Cornell's Legal Information Institute (LII) has endeavored to index the decisions held at all thirteenth circuit sites (http://www.law.cornell.edu/usca/search/) without storing or reformatting their data. As the LII warns users,[23] the task is a daunting one given the court sites' lack of uniformity and the apparent hostility of several to external search engines. While the LII U.S. Circuit Court search manages to penetrate the four circuits that have excluded Google[24] and thereby to enable a full cross-circuit search, it makes no claim to comprehensive coverage.

\section{Commercial Online Sources Other Than Lexis or Westlaw}

I12 While Westlaw and Lexis are the dominant commercial research services and essentially the only ones known by federal judges, government lawyers, large firm lawyers, and legal academics, they do have lower cost competitors. The failure of circuit court web sites to do a more effective job of direct dissemination of Court of Appeals decisions, including the now citable nonprecedential ones, would be less troubling, at least in terms of lawyer access, were these second tier commercial services able to fill the gap. Not surprisingly, their performance is mixed, handicapped in no small way by the limitations of the court sites on which they depend.

ף13 An evaluation of LoisLaw, VersusLaw, CaseMaker and Fastcase in September 2007, using a sample of nonprecedential June decisions drawn from all thirteen circuits yielded the conclusions set out in the following table.[25] 


\begin{tabular}{|c|c|c|c|c|}
\hline Service & $\begin{array}{l}\text { Does the service } \\
\text { include post FRAP } \\
32.1 \\
\text { nonprecedential } \\
\text { decisions? }\end{array}$ & $\begin{array}{l}\text { Does the service } \\
\text { offer a ready way } \\
\text { to limit a search to } \\
\text { precedential } \\
\text { decisions? }\end{array}$ & $\begin{array}{l}\text { What notice does } \\
\text { the service provide } \\
\text { that a retrieved } \\
\text { decision is } \\
\text { nonprecedential? }\end{array}$ & $\begin{array}{l}\text { Does the service } \\
\text { including } \\
\text { significant } \\
\text { numbers of pre } \\
\text { FRAP } 32.1 \text { non } \\
\text { precedential } \\
\text { decisions? }\end{array}$ \\
\hline Loislaw & Yes & $\begin{array}{l}\text { Yes. Loislaw offers } \\
\text { three types of } \\
\text { searches: "published } \\
\text { only, both published } \\
\text { and unpublished, or } \\
\text { unpublished only. }\end{array}$ & $\begin{array}{l}\text { In a mixed search } \\
\text { nonprecedential } \\
\text { opinions are shown in } \\
\text { blue, marked } \\
\text { "Unpublished," and } \\
\text { when opened } \\
\text { prefaced by the } \\
\text { following notice: } \\
\text { "[EDITOR'S NOTE: } \\
\text { This case is } \\
\text { unpublished as } \\
\text { indicated by the } \\
\text { issuing court.]” }\end{array}$ & $\begin{array}{l}\text { The numbers of pre- } \\
2007 \\
\text { nonprecedential } \\
\text { decisions are quite } \\
\text { small even in } \\
\text { circuits that placed } \\
\text { no limits on citing } \\
\text { them prior to } 2007 .\end{array}$ \\
\hline VersusLaw* & Yes & $\begin{array}{l}\text { VersusLaw does not } \\
\text { itself separate } \\
\text { precedential from } \\
\text { nonprecedential } \\
\text { decisions. If the } \\
\text { searcher knows a } \\
\text { phrase the circuit } \\
\text { places consistently } \\
\text { in nonprecedential } \\
\text { decisions that can be } \\
\text { incorporated in a } \\
\text { search to include or } \\
\text { exclude. }\end{array}$ & $\begin{array}{l}\text { In a results list } \\
\text { "unpublished” } \\
\text { decisions are } \\
\text { preceded by “[U]”. } \\
\end{array}$ & $\begin{array}{l}\text { The numbers of pre- } \\
2007 \\
\text { nonprecedential } \\
\text { decisions are } \\
\text { substantial, even in } \\
\text { circuits that barred } \\
\text { their citation prior to } \\
2007 \text {. }\end{array}$ \\
\hline Casemaker & Yes & $\begin{array}{l}\text { Since Casemaker } \\
\text { appears to strip out } \\
\text { the words the } \\
\text { circuits use to } \\
\text { designate } \\
\text { nonprecedential } \\
\text { decisions there is no } \\
\text { way to exclude them } \\
\text { from a search. The } \\
\text { only indication a } \\
\text { decision retrieved by } \\
\text { a search falls in the } \\
\text { nonprecedential } \\
\text { category is the } \\
\text { absence of a Federal } \\
\text { Reporter cite. }\end{array}$ & & $\begin{array}{l}\text { Appears not to hold } \\
\text { pre-2007 } \\
\text { nonprecedential } \\
\text { decisions even in } \\
\text { circuits that placed } \\
\text { no limits on citing } \\
\text { them prior to } 2007 \text {. }\end{array}$ \\
\hline Fastcase & No & & & \\
\hline
\end{tabular}

* Since TheLaw.net uses VersusLaw case data, the VersusLaw evaluation applies to it as well. 


\section{The Challenge of Citing Nonprecedential Decisions and Specific Passages in Them}

T14 Citation reform, prompted by the shift to electronic media and urged upon the nation's courts in the late 1990s, found little support among federal judges. Despite strong recommendations and blueprints from the American Bar Association (ABA) and American Association of Law Libraries (AALL) augmented by advocacy on the part of the Justice Department's Antitrust

Division, the proposal moved nowhere with the federal courts.[26] Rule 32.1 ought to reopen the matter. Strong as the arguments are for using court-applied sequence and paragraph numbers instead of volume and page numbers drawn from the commercially produced Federal Reporter as the core citation elements for precedential decisions, they become even more compelling when applied to the more numerous nonprecedential ones. Consider the following example. On January 4, 2007, the Federal Circuit released an eleven-page nonprecedential decision in the case of DESA IP, LLC. v. EML Technologies, LLC. With a system of non-proprietary and medium neutral citation of the sort that nearly one-quarter of the states have now adopted, one could cite to the court's discussion of the weight to be given expert testimony in that case as follows:

DESA IP, LLC. v. EML Techs., LLC., 2007 USApp (Fed) 1 NP, \17.

While the formats recommended by the ABA and AALL vary in some details (which have been merged in the example), they share the following key elements:

1. Case designations consist of the year (“2007” in this case), an abbreviation identifying the court ("USApp(Fed)"), and a sequence number. (DESA IP being the first decision issued by the Federal Circuit in 2007 it is, following this approach, numbered “ 1 ”.)

2. Nonprecedential or unpublished decisions carry an indicator of that status following their number ("NP" in the example).

3. Court-attached paragraph numbers (e.g., “\$17”) capable of following the text into any and all media provide the means for citing specific portions of an opinion (pinpoint citation).

q15 Compare the current alternatives for nonprecedential Court of Appeals decisions. A principal aim of Thomson / West's publishing the bulk of these decisions in a little-used reporter has been to establish its volume and page numbers as the standard means of citation. Using them, of course, requires waiting until the decision has been placed in a Federal Appendix volume. More importantly it also requires access to Westlaw or one of the two other services 
that license Federal Appendix pagination from Thomson - Lexis and LoisLaw. Professional practice rooted in print technology would turn, as an alternative, to the pagination of the court's "slip opinion" for a pinpoint reference. While some circuit courts place their decisions online in a format (pdf) that preserves particular pagination, the major online systems replace it with their own. Paragraph 17 of the DESA IP opinion straddles pages 936 and 937 of the Federal Appendix. Lexis would have its subscribers cite that paragraph as "2007 U.S. App. LEXIS 256, at*12." A pinpoint cite to the same paragraph on Westlaw would read "2007 WL 79066, at *4." While the text in question falls on page 8 of the slip opinion, available online at http://www.fedcir.gov/opinions/06-1168.pdf, none of the commercial services preserves that information and all their alternatives are proprietary. It is time for the Judicial Conference of the United States to revisit the need for a courtapplied system of neutral citation.

\section{The Need for a More Coherent Federal Judicial Data System}

ף16 The Judicial Conference should also address the wide variance among circuit court implementations of the E-Government Act. A first step might take the form of minimum standards supporting the Act's attempt to assure reasonable access to the collective jurisprudence of the thirteen circuits, combined with periodic recognition of "best practices" among circuit sites. Specific goals for such an effort could include at least: 1) reasonable text search functionality at all federal court sites across all decisions, precedential and nonprecedential, 2) a form of designating nonprecedential decisions sufficiently distinctive and uniform to allow their exclusion from a full-text search, both within one circuit and across all of them, 3) the opening of all circuit opinion archives to external search engines; and 4) the coding of all decisions released in digital form with basic metadata (e.g., opinion author, docket number, date, court, and court attached citation). So long as the federal courts continue to rely so completely on Thomson / West to compile their decisions in final citable form and on Westlaw and Lexis for access to their own case law, issues of greater public access, and encouragement of competition from other online providers, are all-too-likely to be neglected. Leadership from the Judicial Conference similar to that which produced FRAP 32.1 is called for. Since the chair of the Conference, Chief Justice Roberts, played a key role in that effort such leadership is not unthinkable.

\section{A Readily Attainable Vision}

I17 If one launches a Google search using no more than the standard citation to a decision of the U.S. Supreme Court (e.g., 504 U.S. 555), having no knowledge of which sites might offer it, the retrieval list links to multiple versions of the specified decision. Similarly, if one enters the court applied citation of a 
decision of the Ohio, Oklahoma, or North Dakota Supreme Court (e.g., 2006-

Ohio-6711, 2007 OK 59, or 2007 ND 23), the search retrieves the cited decision in the official form held at the court site. It should not be too much to expect of the federal courts that they would implement the E-Government Act with sufficient thoroughness and consistency that a Google or LII search of circuit court decisions could retrieve relevant recent cases from all thirteen court sites, precedential, nonprecedential, or both. Add citation reform and the cases retrieved from the court sites could be in final, official, and citable form. Absent those steps, the wide availability of federal case law "at little or no cost" which Justice Alito’s committee imagined resulting from the E-Government Act will remain a mirage.

* (C) Peter W. Martin, 2008. This work is licensed under the Creative Commons AttributionNoncommercial-ShareAlike 3.0 License. To view a copy of this license, visit http://creativecommons.org/licenses/by-nc-sa/3.0/ or send a letter to Creative Commons, 543 Howard Street, 5th Floor, San Francisco, California, 94105, USA.

** Jane M.G. Foster Professor of Law, Cornell Law School, Ithaca, New York, and cofounder, Legal Information Institute.

[1] FRAP 32.1, available at http://judiciary.house.gov/media/pdfs/printers/109th/31307.pdf.

[2] See Stephen R. Barnett, No-Citation Rules Under Siege: A Battlefield Report and Analysis, 5 J. App. Prac. \& Process 473, 475 (2003), available at http://ssrn.com/abstract=485823.

[3] Pub. L. No. 107-347 § 205 (a)(5), available at http://www.access-tolaw.com/elaw/readings/egovernment_act_2002.pdf.

${ }^{[4]}$ Memorandum from Hon. Samuel A. Alito to Hon. David F. Levy, at 4 (May 6, 2005), available at http://www.uscourts.gov/rules/Reports/AP5-2005.pdf.

[5] $I d$. at 6 .

[6] Id.

[7] See Administrative Office of the U.S. Courts, 2005 Annual Report of the Director 44, available at http://www.uscourts.gov/library/annualreport05_innovations.html\#research.

[8] There are a few exceptions. See Andrew T. Solomon, Making Unpublished Opinions Precedential: A Recipe for Ethical Problems \& Legal Malpractice?, 26 Miss. C.L. Rev. 185 (2006/2007), available at http://ssrn.com/abstract=1001952.

[9] See Judicial Business of the United States Courts: 2007 Annual Report of the Director tbl. S3, available at http://www.uscourts.gov/judbus2007/tables/S03Sep07.pdf. These figures do not include the Federal Circuit which issues several hundred nonprecedential decisions a year. During the first six months of 2007, for example, it produced 359 opinions of which 217 or 
60.4\% were unpublished. See Federal Circuit Opinions, Orders \& Decisions, http://www.fedcir.gov/dailylog.html.

[10] See Solomon, supra note 8, at 193.

[11] In contrast, the states, amost without exception, took on case law dissemination as a public responsibility during the nineteenth century. See Peter W. Martin, Reconfiguring Precedent and the Concept of Precedent for a Digital Age, Cornell Legal Studies Research Paper No. 07-013, ฯฯ16-20, available at http://ssrn.com/abstract=1010766.

${ }^{[12]}$ Brian P. Brooks, Publishing Unpublished Opinions: A Review of the Federal Appendix, 5 Green Bag 2d 259 (2002).

[13] See Law-Lib: closing tally on subscribing to Federal appendix, http://lawlibrary.ucdavis.edu/LAWLIB/Nov01/0180.html. In the hundreds of law libraries supporting the work of the U.S. Justice Department there is but one copy of the Federal Appendix. Telephone interview with Daire McCabe, Co-Chief, Acquisitions, Department of Justice Library, Sept. 17, 2007.

[14] E-mail from Kay Guillot, Circuit Librarian, U.S. Court of Appeals for the Fifth Circuit, to author (Sept. 14, 2007) (on file with author); E-mail from Jerry Stephens, Librarian, U.S. Court of Appeals for the Tenth Circuit, to author (Sept. 17, 2007) (on file with author); E-mail from Ellen Strbak, Legal Resources/ILS Program Administrator, Administrative Office of the U.S. Courts, to author (Sept. 26, 2007). Federal judges have been urged by the Judicial Conference of the United States to "maintain only those subscriptions to print case reporters deemed essential to chambers." See Report of the Proceedings of the Judicial Conference of the United States, September 20, 2005, at 18, available at http://www.uscourts.gov/judconf/sept05proc_final.pdf.

${ }^{[15]}$ See http://west.thomson.com/product/40015694/product.asp.

${ }^{[16]}$ Westlaw itself contains 4012006 decisions in its unpublished Courts of Appeals database that have no Federal Appendix citation. Lexis contains 2,951 Court of Appeals decisions for the same year that have neither a Federal Reporter nor a Federal Appendix citation. (The search yielding the latter count was: "cites (2006 U.S. App.) and not cites (fed appx) and not cites (f.3d)".)

[17] A narrower interpretation of the "text searchable format" requirement and that seemingly held by the Administrative Office of the Courts is that decisions must be loaded on court sites as text rather than image files but that providing the capacity to search is not the court's responsibility. See Federal Courts Respond to E-Government Act, 37 The Third Branch, April 2005, available at http://www.uscourts.gov/ttb/apr05ttb/respond/index.html.

${ }^{[18]}$ Those are the First, Second, Third, Fourth, Fifth, Eighth, Ninth, and Tenth Circuits.

[19] As of April 25, 2008, a search at http://www.ca1.uscourts.gov/ on the words "copyright” and "infringe" and other frequently occurring terms retrieved no decisions more recent than 2001.

[20] The Ninth Circuit site, http://www.ca9.uscourts.gov/, divides decisions into two categories, opinions and memoranda, and offers search only of the first. The court's nonprecedential memorandum decisions are simply listed by date. As of April 25, 2008, searches of opinions using frequently occurring terms retrieved failed to retrieve decisions more recent than 2000. 
[21] See http://www.courts.state.me.us/opinions/supreme/index.html.

[22] The site of the D.C. Circuit is particularly disappointing. The court allows all unpublished orders and judgments handed down since January 1, 2002, to be cited as precedent. See D.C. Cir. Rule 32.1(b)(1)(B). But the court's site provides no clear path to them, offers no word search capability, and is closed to external search engines. The fact that Georgetown maintains a searchable archive of D.C. Circuit opinions (precedential only) may explain the limitations of the circuit's site. A similar excuse exists in the case of the Fourth (Emory) and Tenth (Washburn).

${ }^{[23]}$ See http://www.law.cornell.edu/usca/search/disclaimer.html.

${ }^{[24]}$ It is possible to search opinions across most of the circuits Google does index by including the term: site:www.*.uscourts.gov. That, however, sweeps in all U.S. District Courts open to Google with domain names in that pattern and documents other than opinions at the court sites.

[25] Thomson's Findlaw site was not included in this evaluation since it neither provides citation information on Court of Appeals cases nor includes nonprecedential decisions.

[26] See Peter W. Martin, Neutral Citation, Court Web Sites, and Access to Authoritative Case Law, 99 Law Libr. J. 329, 952 (2007), available at http://www.access-to-law.com/elaw/pwm/access to_caselaw01.htm\#52. 